نقش كرمهاى خاكى (ايزينيا فتيدا) در فراهمى زيستى خاكهاى آلوده به فلزات سنخين

$$
\text { قاسم رحيمى" و فيروزه نوروزى كلدره' }
$$

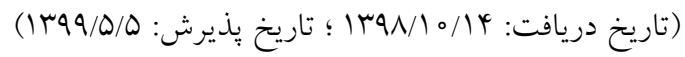

جكيده

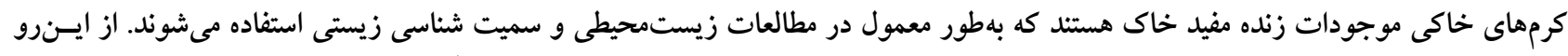

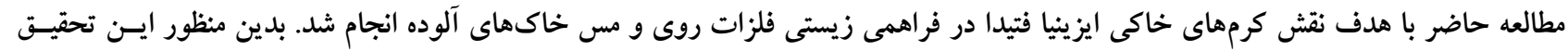

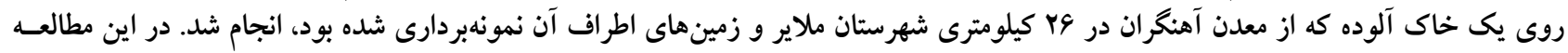

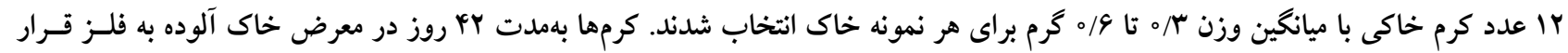

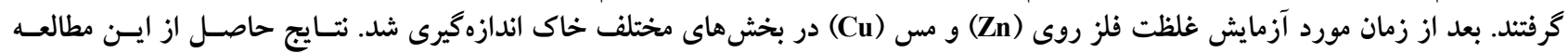

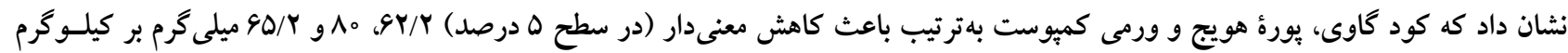

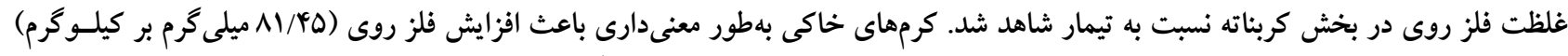

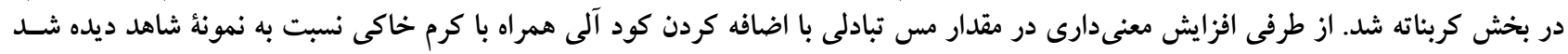

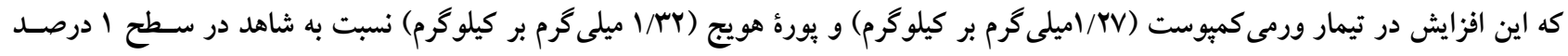
معنى دار شد.

وازههاى كليدى: بخشبندى فلزات، كرمهاى خاكى، فلزات مس و روى 
معمول در مطالعات زيستمحيطى و سـنجش سـميت زيستى

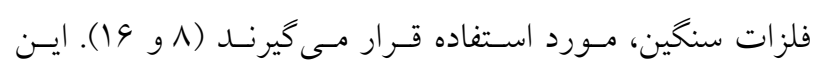

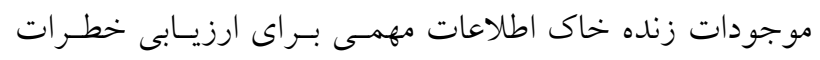

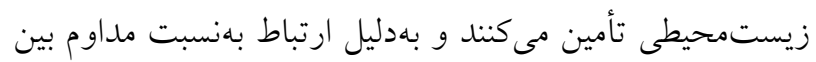

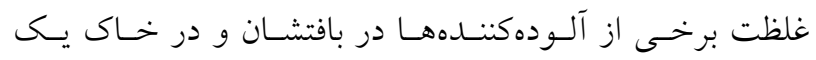
شاخص مفيد بيولوزيكى براى ارزيابى آلودكى بهحساب مى بـ آيند

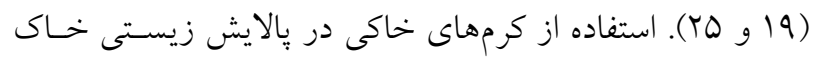

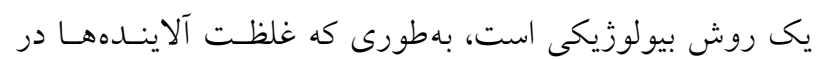

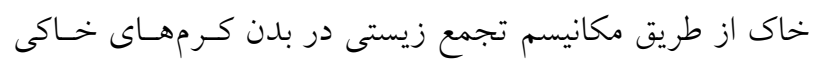

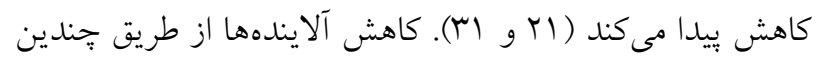

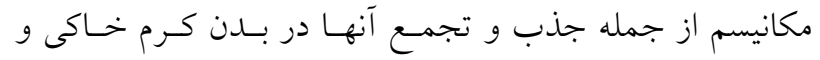

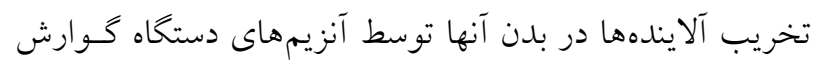

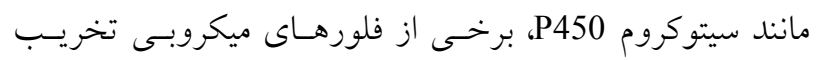

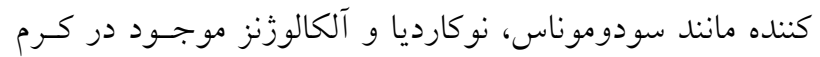

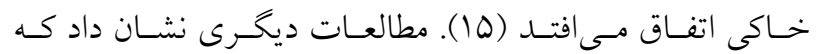

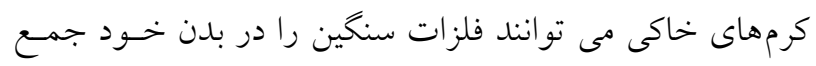

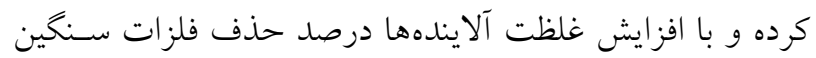
را از خاك افزايش دهند (Y) آن). تجمع فلزات سنخين توسط كرمهاى خاكى مى تواند بسته به

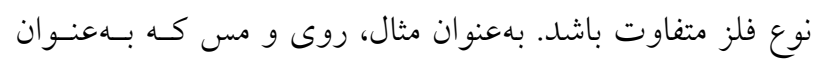

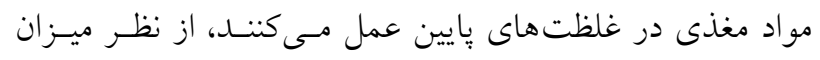

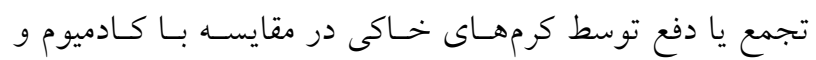

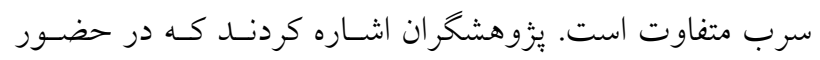

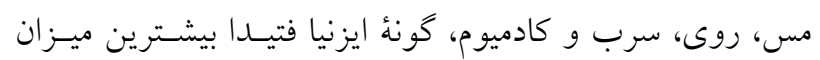

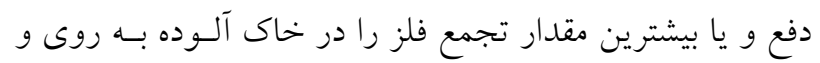

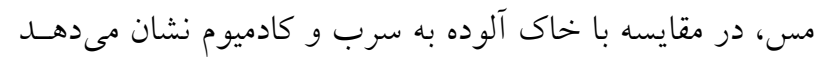

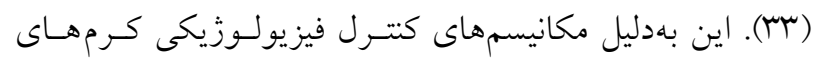
خـاكى اسـت و همجينـين بـهدليـل اينكـهـ مسس و روى فلـزات ضرورى براى فعاليت (ب أ) اركانيسم هستند. بلهور كلى حضور كرمهاى خاكى در محيط خاك مى توانـــ

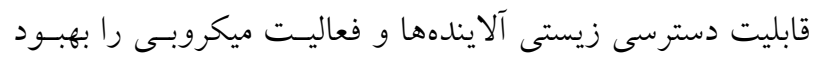
ببخشد كه منجر به تجزيه ميكروبى بيشتر آلايندهاى خاك مسى

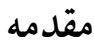

يكى از مهم ترين آلودكىهاى زيستمحيطى كه سلامت انسـان

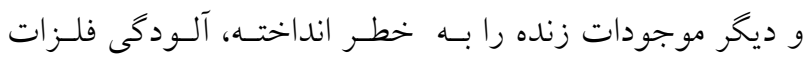

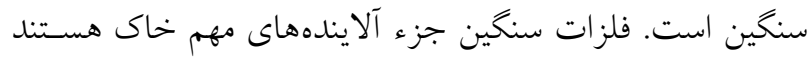

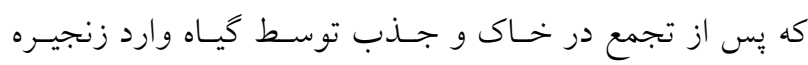

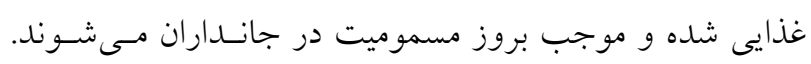

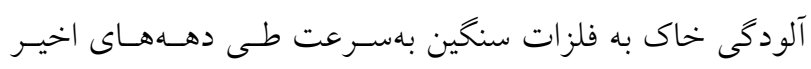

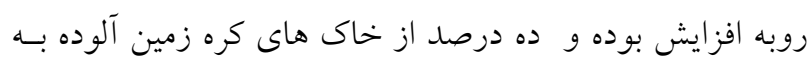

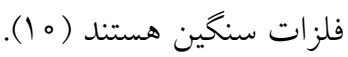
در مناطق متعددى كه تحت تأثير فعاليتهاى معــدن هسـتند

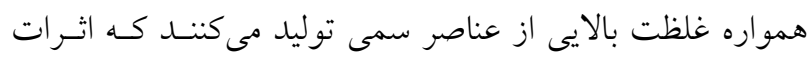

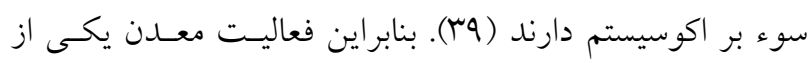

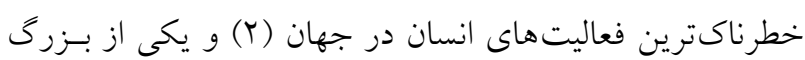

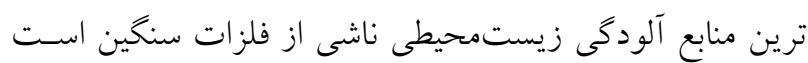

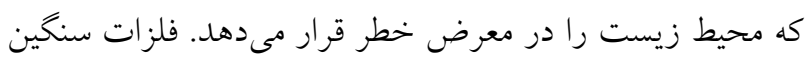
داراى ويزگى هايى نظير: تجمع يذيرى زيستى، سميت بالا، ثبـات

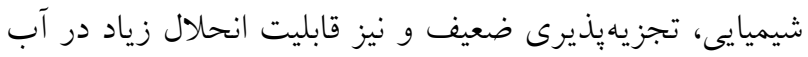

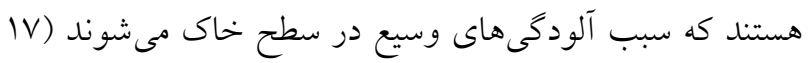

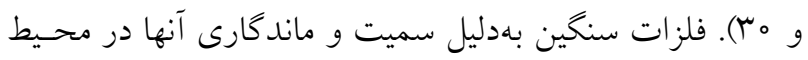
زيست تهلديدى جدى براى سلامت جامعه به حسـاب مسى آينــ

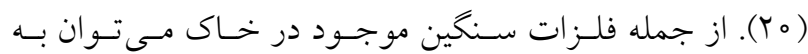

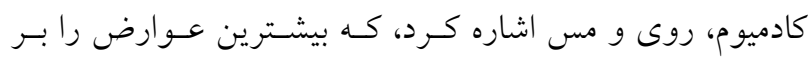

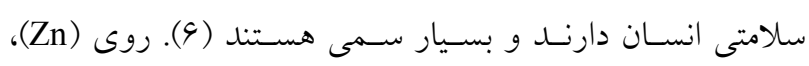

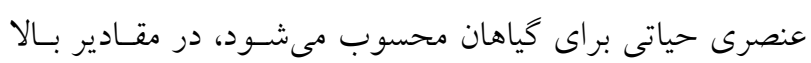

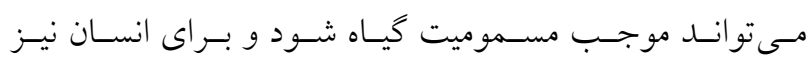

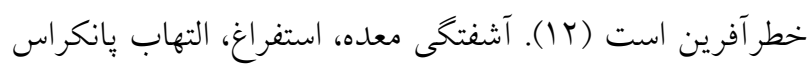

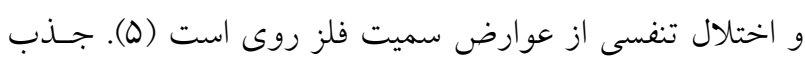

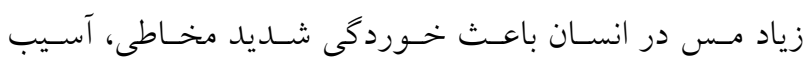
كسترده مويركى، تغيييرات نكروتيكى كبـدى و كليـوى، دسـيكاه

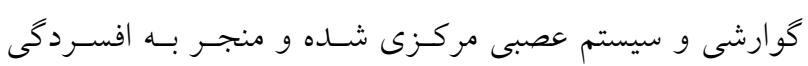

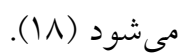

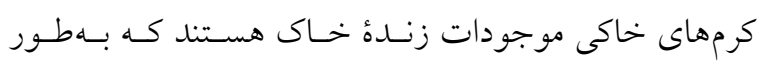




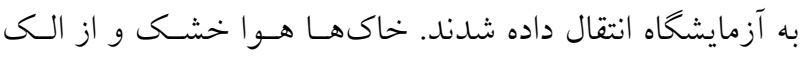
(بmm r)

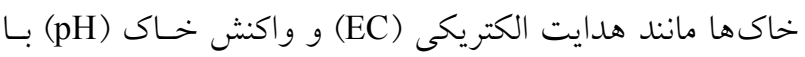

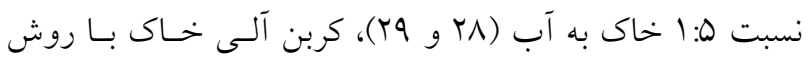

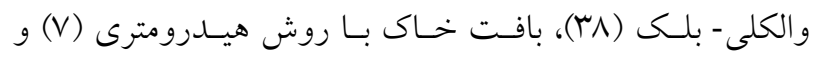

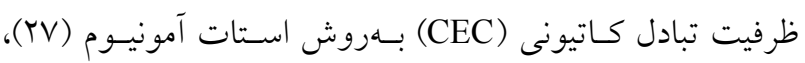
مورد بررسى قرار گرفت. اندازهكيرى غلظت كل فلزات سـنخين در خاك بهروش اسبوزيتو و همكاران (بYM)، بـا هضـم اسـيدى

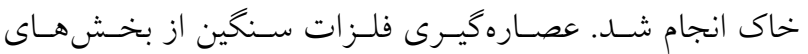
مختلف خاك براى تعيين غلظت فلزات در بخشهـاى مختلـف

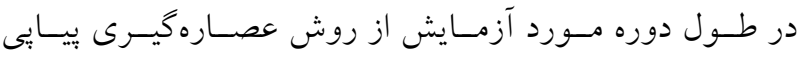

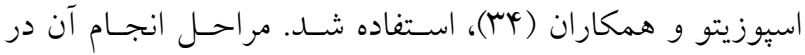
جدول ا نشان داده است. غلظت فلزات سنخين در نمونههاى به دست آمده توسط دستخاه اسِيكتروفتومتر جـــب اتمسى مــدل r Tro Varian آمادهسازى نمونهها: اين آزمـايش بـهـهـورت فاكتوريـل در

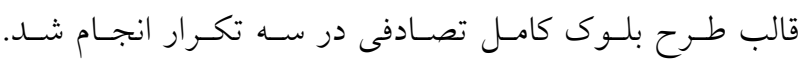

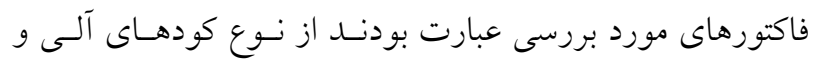

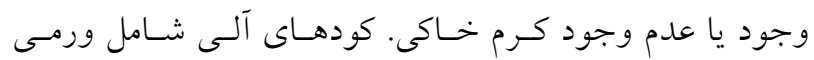

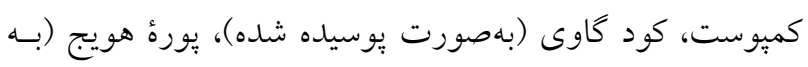

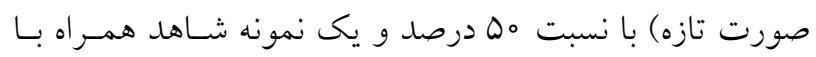

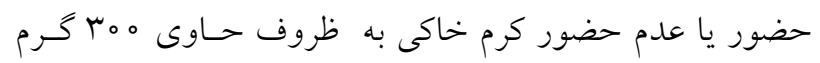

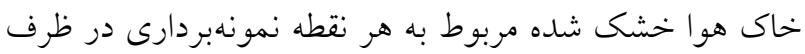

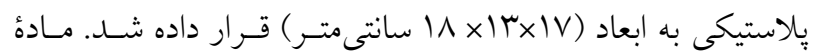

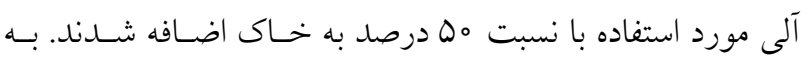

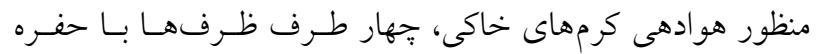

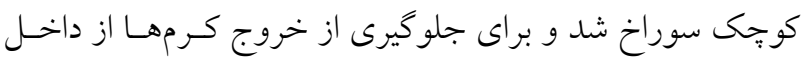

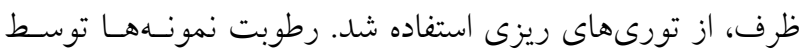

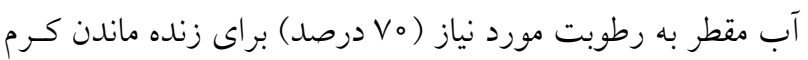

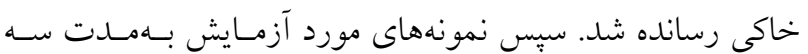
روز بهمنظور ايجاد تعادل بين رطوبـت خـاك و تيمارهـاى مـورد

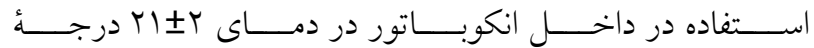

شود، همجنين از جمله مهمترين موارد كـاربرد ايسن موجـودات

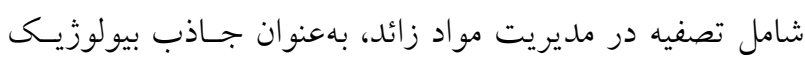

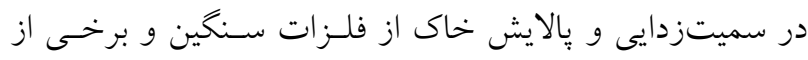

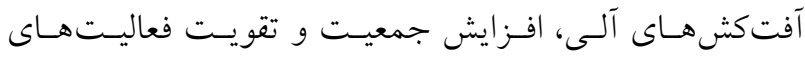

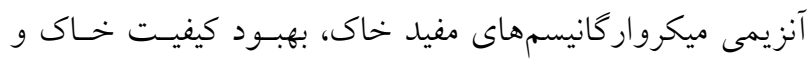

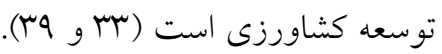

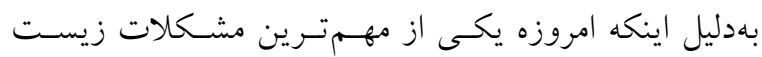
محيطى در سراسر دنيا آلودكى خاكهاى مناطق صنعتى و معادن

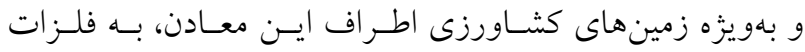
سنگين نظير، سرب، كادميوم، مس، روى، كروم و غيره اسـت و بهدليل اينكه استفاده از كرمهاى خاكى روش بيولوزيكى مناسبى براى حذف اين فلزات از محيط خـاك اسـت، ايسن مطالعهـ بـهـ

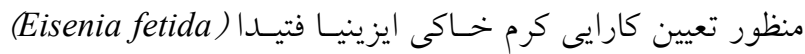

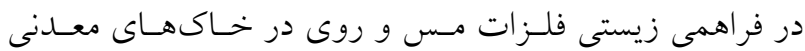
آلوده به اين فلزات به اجرا در آمد.

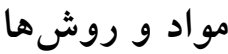

منطقه مورد مطالعه: اين تحقيق روى يك خاك آلوده طبيعى كـهـ از معدن سرب و روى آهنخران و زمينهاى اطراف آن كه كـمو

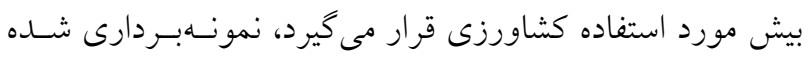

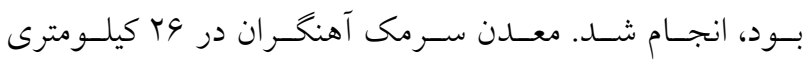

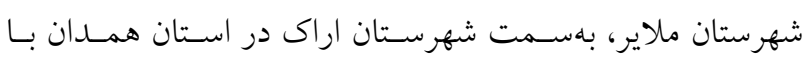

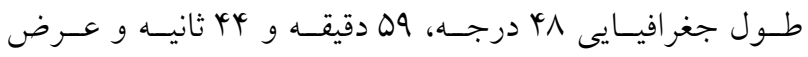
جغر افيايى بr درجه، ه 1 دقيقه و هب ثانيه واقع شده است.

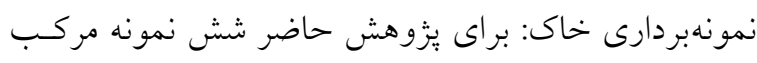

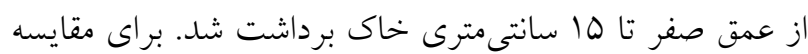

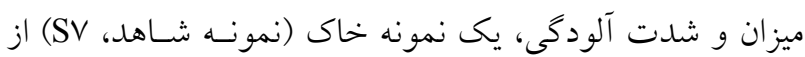
مناطق شاهد (اطر اف دانشكده كشاورزى دانشگاه بـوعلى سـينا)

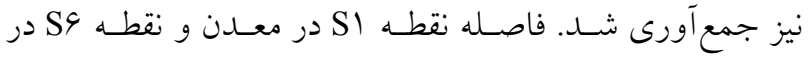
دورترين فاصله از معدن (يكى كيلومترى معدن سرمك آهنـــران

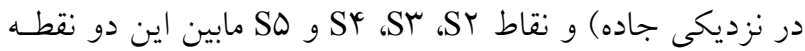
قرار گرفتند. نمونههاى خاك در داخل كيسه يلىاتسيلن ريختسه و 
جدول ا. عصاره گيرها و شرايط آزمايش براى تعيين بخشهاى مختلف فلز سنخين بهروش اسبوزيتو

\begin{tabular}{|c|c|c|}
\hline فرم فلزات سنخين & مدت زمان شيك كردن & عصارهگير \\
\hline بخش تبادلى & عاساعت (در دماى آزمايشگاه ) & ها ميلى ليتر نيترات يتاسيم ه/ه مولار \\
\hline بخش بييوند به مواد آلى ل & عاساعت (در دماى آزمايشگاه ) & هr ميلى ليتر هيدروكسيد سديم ه/ه مولار \\
\hline بخش بيوند به كربنات & 9 ساعت (در دماى آزمايشخاه ) & هr ميلى ليتر EDTA هـ \\
\hline بخش باقى مانده & צاساعت (در دماى آزمايشگاه ) & ه ميلى ليتر r \\
\hline
\end{tabular}

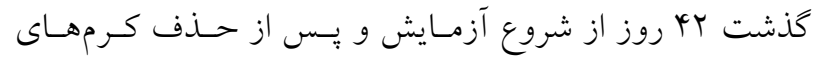

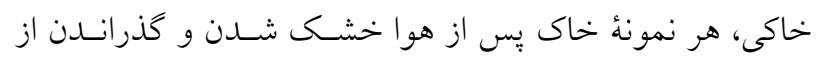

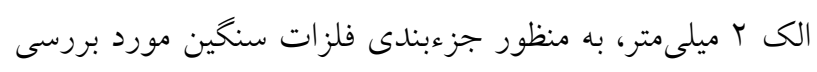
قرار گرفت. تجزيسهو تحليـل آمـارى: تجزيــه واريـانس دادههــا بـهروش

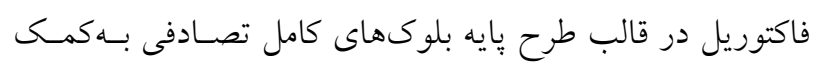

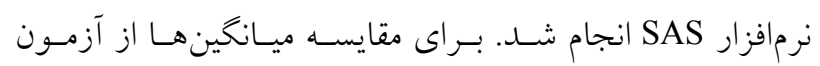
دانكن در سطح احتمال ه درصد استفاده شد.

\section{بحث و نتايج}

خصوصيات فيزيكى و شيميايى خاكهاى مورد مطالعـه: نتـايج تجزيه واريانس خصوصيات فيزيكى و شـيميايى خـاك نمونـه بردارى شده از نقاط مختلف (جدول r) نشان مىدهد كه مقدار

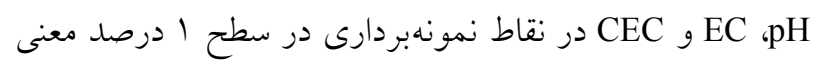
دار بود. با توجه به جدول س، pH خاكهاى مناطق اطراف معدن

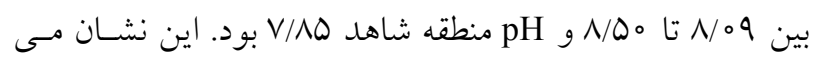
دهد كه pH خاكهاى منطقه مورد مطالعـه قليـايى بــوده اسـت.

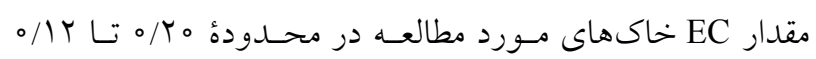
دسىزيمنس بر متر (dS/m) بود كه نشاندهندهُ يايين بودن ميزان شورى مناطق مورد مطالعه است (جدول (ا). كمترين و بيشـترين

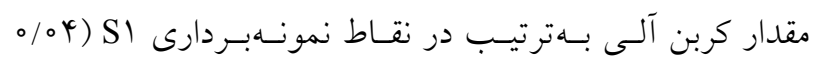
درصد) و SY SY (T/Y درصد) مشاهده شد كه تفاوت معنسى دارى بين اين نقاط با ساير نقاط نمونهبردارى ديله شد. ظرفيت تبادل

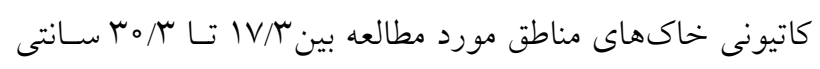

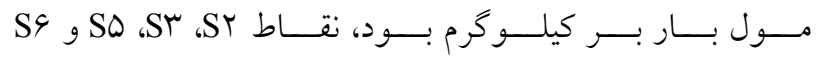

سانتى گراد قرار داده شدند. آمادهسازى كرم خاكى : كرم خاكى مورد استفاده، ايزينيا فتيدا از شاخه كرمهاى حلقوى، خانواده لومبريسيده (Lumbricidae)، جنس ايزينيا و گونه فتيدا بود كه از شـركت ورمسى كمبوسـتينخ كه توليد كننده و عرضه كننده كرم ايزنيـا فتيــا واقـع در اسـتان البرز است، تهيه شد. همه كرمهاى خاكى بهمدت دو ماه قبـل از

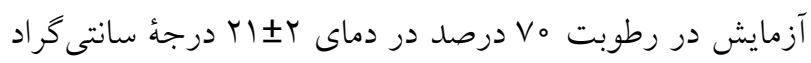
با دورهٔ نورى 19 ساعت روشنايى و ^ ساعت تاريكى در داخـل انكوباتور كشت شدند (YY). آزمايش سميت كرمهاى خاكى : سه روز بعد از ايجاد تعادل

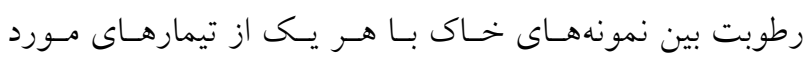

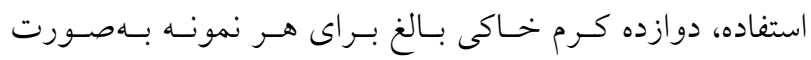

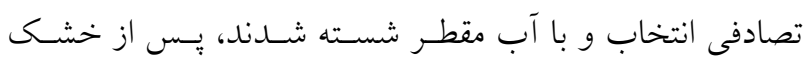

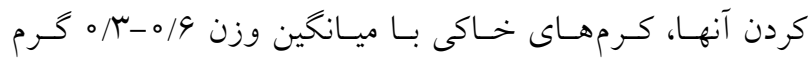
انتخاب شدند. بهمنظور خارج كردن محتويـات روده كـرمهـاى خاكى از ذرات خاك، كرمهاى خاكى در بترى ديشهاى شيشـه اى (V) علد كرم در هر ظرف) شامل كاغذ واتمن با جنــ قطـره آب مقطر براى حفظ رطوبت، در دماى \1 درجه سانتى گراد بـه

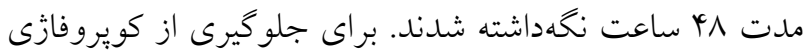
كاغذ واتمن هر با ساعت عوض مسىشــ (r). بـس از تخليــ

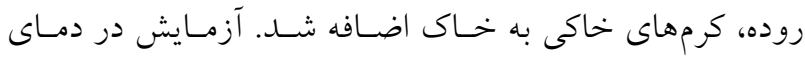
r I ا با دورة نورى 19: 1 ساعت تاريكى و روشنايى انجام شد و در طول اجراى آزمايش هيج نوع غذايى بـه ظـرفهــا اضـافه نشد. در طول اجراى آزمايش كرمهـاى خـاكى مـرده بـهمنظـور جلو گيرى از اثر آنها بر كرمهاى ديخر حذف مى شـــند. يسـ از 
جدول r. تجزيه واريانس خصوصيات فيزيكى و شيميايى خاك نمونهبردارى شده از نقاط مختلف

\begin{tabular}{|c|c|c|c|c|c|}
\hline & خين مربعات & & & & \\
\hline ظرفيت تبادل كاتيونى & هدايت الكتريكى & كربن آلى & $\mathrm{pH}$ & منبع ير اكنش & درجه آزادى \\
\hline$\Delta^{* * *}$ & ○/००ケ** & $\circ / 99^{* *}$ & $\circ / \circ \wedge^{\mathrm{ns}}$ & 4 & نقاط نمونهبردارى \\
\hline$\circ / \Lambda \Lambda$ & ०/००० & $0 / 01$ & $0 / 0 Y^{x}$ & Ir & خطا \\
\hline$\Delta V / 0 Y^{\mathcal{C}}$ & $9 V / 9$ & $\Lambda Q / \circ \mathcal{Y}^{c}$ & I/VA & - & $F$ value \\
\hline
\end{tabular}

جدول r. خصوصيات فيزيكى و شيميايى خاك نمونهبردارى شده از نقاط مختلف

\begin{tabular}{|c|c|c|c|c|c|c|c|c|}
\hline بافت & شن & سيلت & رس & $\begin{array}{c}\text { ظرفيت تبادل كاتيونى } \\
\text { (Cmolc/kg) }\end{array}$ & كربن آلى & $\begin{array}{c}\text { هدايت الكتريكى } \\
\text { (ds/m) }\end{array}$ & $\mathrm{pH}$ & \\
\hline لوم شنى & $\Delta r / \Lambda$ & 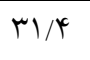 & $14 / \Lambda$ & $\mathrm{IV} / \mathrm{T}^{\mathrm{d}}$ & $\% / 0 \mathrm{yd}$ & $\circ / Y_{\circ} a$ & $\Lambda / Y^{\mathrm{ab}}$ & SI \\
\hline لوم رسى & Tr/r & ra & $\mu \circ / \Lambda$ & $r \Lambda / V^{a}$ & $\circ / 9 V^{b}$ & $\circ / 14 b$ & $N / \circ q^{a b}$ & ST \\
\hline لوم رسى & $\psi^{\prime} \mid / r$ & MT & $r G / \Lambda$ & $r q / \wedge^{\mathrm{a}}$ & $r / r \varphi^{a}$ & $\circ / r_{\circ} a$ & $\Lambda / 0^{a}$ & Sr \\
\hline لوم رسى & $T V / T$ & re & re/A & $Y Y / Q^{c}$ & $\circ / 9 \Lambda^{\mathrm{c}}$ & $\circ / 11 \mathrm{c}$ & $\Lambda / r Q^{\mathrm{ab}}$ & SY \\
\hline لوم & אr/A & $r q / r$ & TH/A & $\mu \circ \mu^{a}$ & $\circ / 09^{c}$ & $\circ / 11^{c}$ & $\Lambda / 1 Q^{\mathrm{ab}}$ & SO \\
\hline رس & $r M / r$ & MG/9 & $Y Y / T$ & $r q / \varphi^{c a}$ & $0 / 99^{\circ}$ & $\circ / 11^{c}$ & $\Lambda / Y^{\mathrm{ab}}$ & S9 \\
\hline لوم رسى شنى & $\Delta Q / Y$ & ro & $Y Y / \Lambda$ & $r G / 4 b$ & $\circ / \Lambda \Delta^{c}$ & $\circ / / \mu^{\mathrm{b}}$ & $\Lambda / \wedge \Delta^{\mathrm{b}}$ & SV شاهد SV \\
\hline
\end{tabular}

مس (999 ميلى گـرم بـر كيلـو گرم) در نقطـه ST يافـت شــ و كمترين مقدار ميانخين مس ابتدا در نقطهُ S9 سبس در نقطئ SY يافت شد. غلظت فلز مس در نقاط سك، SY با ساير نقـاط معنسى دار بود (جدوله). سازمان بهداشت جهانى (WHO)، حد مجـاز

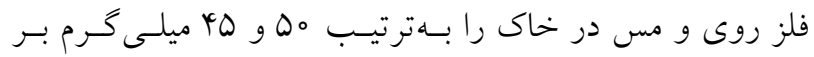
كيلوگرم اعلام كرده است بنابراين حضور مقـادير بـالاتر از ايسن ميزان در خاك، نشان دهنده آلودكى فلز روى و مسس در خـاى است. بر اساس اين نتايج غلظت فلز روى و مس در تمام نقـاط نمونهبردارى (بهجز SV) در حد بحرانى بود.

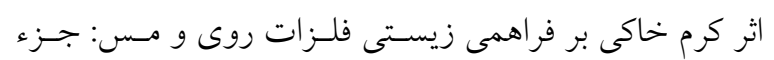

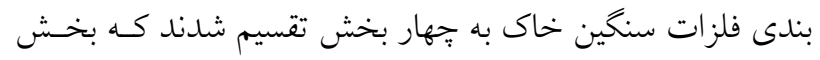
محلول و تبادلى، تركيبـات قابـل اسـتفاده زيسـتى هـر فلـز بـود، درحالى كه جزء كربناته بخش فلزات رسوب شده بـا كربنـاتهـا
بيشترين ظرفيت تبادل كاتيونى را دارا بودند. همجنين خاكهاى

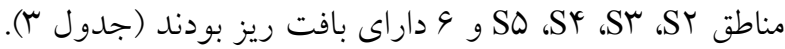
غلظت فلزات سـنخين در خــاكهـاى مـورد مطالعـه: نتـايج جدول تجزيـه واريـانس فلـز سـنخين در نقـاط نمونـهبــردارى (جــدول †) نشـان مسىدهـد غلظـت دو فلـز ســخين در نقـاط نمونهبردارى در سطح ا درصد معنىدار بـود؛ بنـابراين مقايسـه ميانخين فلزات سنخين در اين نقاط مورد بررسى قرار خرفت و در جدول ه آورده شده است (جـدول ه). بيشـترين و كمتـرين

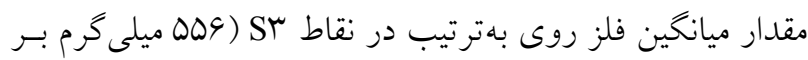

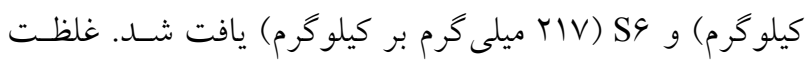
فلز روى در نقطهُ س ST با نقطة SY تفاوت معنى STارى را نشان نداد درصورتى كه تفاوت معنى دارى در نقطهُ س با ساير نقاط بــراى غلظت فلز روى ديده شد (جدوله). بيشـترين مقـدار ميـانخين 
جدول f. تجزيه واريانس غلظت كل فلزات سنخين در نقاط مورد مطالعه

\begin{tabular}{|c|c|c|c|}
\hline \multicolumn{2}{|c|}{ ميانخين مربعات } & \multirow[b]{2}{*}{ درجه آزادى } & \multirow[b]{2}{*}{ منبع يراكنش } \\
\hline $\mathrm{Cu}$ & $\mathrm{Zn}$ & & \\
\hline$|V G| G Y^{* * *}$ & $9 \mu_{0} \circ q^{* * * * *}$ & 9 & نقاط نمونهبردارى \\
\hline$K Y / Y$ & $r \mu \circ \Lambda$ & M & خطا \\
\hline
\end{tabular}

جدول ه. ميانگين (土 خطاى معيار) غلظت كل فلزات سنگين (ميلى گرم بر كيلو گرم) در نقاط مورد مطالعه

\begin{tabular}{|c|c|c|c|c|c|c|c|}
\hline شاهد SV & S\& & $\mathrm{SQ}$ & SY & $S^{r}$ & ST & SI & \\
\hline $10 / 4 \Delta \pm \circ / \Delta^{d}$ & $r \mid V \pm \wedge / V^{c}$ & $r \mu \Psi \pm 1 \circ / \mu^{2}$ & $r \wedge q \pm 9 / 9^{\circ}$ & $09 \varphi \pm r r / V^{a}$ & $019 \pm m / N^{a b}$ & $\kappa \psi r \pm \Delta \mu^{\prime} / \Lambda^{b}$ & $\mathrm{Zn}$ \\
\hline$r q / 19 \pm 0 / \Lambda^{d}$ & $\varphi \varphi / l \pm \varphi / l^{d}$ & $V_{0} / q \pm 1 / \mu^{c d}$ & $\mu \Delta / r \pm \circ / \Gamma^{d}$ & $r Y \wedge \pm \mid Q / V^{b}$ & $999 \pm r \mid / l^{a}$ & $\Lambda 1 / 4 \pm 1 / \Delta^{c}$ & $\mathrm{Cu}$ \\
\hline
\end{tabular}

حروف متفاوت در هر رديف نشاندهندة وجود تفاوت معنىدار بين نقاط نمونهبردارى با استفاده از آناليز مقايسه ميانخين دانكن (P<०/00 ) است.

جدول צ. نتايج تجزيه واريانس اثر كود آلى و كرم خاكى بر بخشبندى فلز روى

\begin{tabular}{|c|c|c|c|c|c|}
\hline \multicolumn{4}{|c|}{ ميانگين مربعات } & \multirow[b]{2}{*}{ درجه آزادى } & \multirow[b]{2}{*}{ منبع براكنش } \\
\hline بخش باقى مانده & بخش كربناته & بخش آلى & بخش تبادلى & & \\
\hline$r m a \wedge^{n s}$ & $0191^{*}$ & $99 V Y^{\mathrm{ns}}$ & $1 / / K^{\mathrm{ns}}$ & $r$ & كود آلى \\
\hline $9 \mathrm{~V} / 9 \circ \mathrm{ns}$ & $\Lambda \Lambda \circ \mu^{*}$ & INYryns & $0 / 9 Y^{\mathrm{ns}}$ & 1 & كرم خاكى \\
\hline$\| \Lambda^{\mathrm{ns}}$ & srans & $\left.\varphi \wedge \Lambda\right|^{\mathrm{ns}}$ & $\Gamma_{\Lambda} / \Upsilon^{\mathrm{ns}}$ & r & كود آلى × كرم خاكى \\
\hline pqr & $\Lambda \mu / \varphi$ & KY & $r / q 1$ & 101 & خطا \\
\hline
\end{tabular}

وss " به ترتيب نشاندهنده معنىدار نبودن و معنىدار بودن در سطح ه درصد است.

مقايسه ميانكين بخشبندى فلـز روى نشـان مسىدهـد كـه كـود

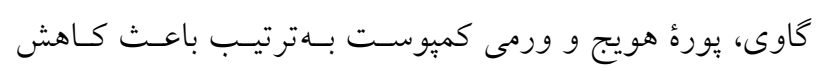
معنى دار (در سطح ه درصـد) ( كيلوگرم غلظت فلز روى در بخش كربناته نسبت به تيمار شاهد شد (شكل (1). در مطالعهاى بر سه نوع خاك، نشـان داد كـه بـاــا افزودن مواد آلى جامد، غلظت فلز روى در بخش كربناته كاهش

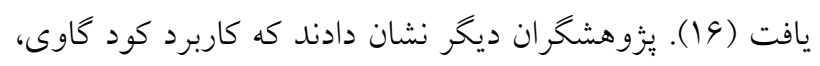
از اسيدى شدن خاى جلو گيرى مى كند و فراهمى زيستى فلزات

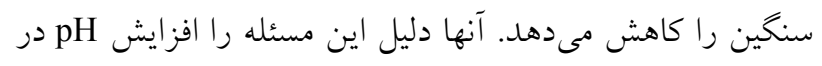

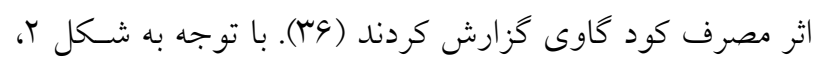
كـرمهــاى خــاكى بــهــــور معنـى دارى باعـث افـز ايش فلـز
است كه قابليت استفاده زيستى ندارد. اين بخش به تغييرات pH حساس است. فلزهاى بخش آلى مى تواند با ريخـت هــاى مـواد آلى از طريق فرايندهاى كميلكس شدن و تجمع زيسـتى همـراه

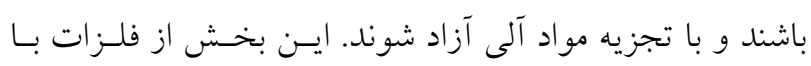
تغيير شرايط، توانايى تحرى دارند. جزء بـاقىمانـده، بخشسى از فلزها هستند كه بهشكل بيوندهاى محكــم اكسـيدى، رسـوب و و كميلكس هاى قوى بهصـورت نسـبتاً بايسـار بــوده و در شـرايط كوناكون تغييرات قابل جشمخيرى بيدا نمى كنند (11). نتايج جدول تجزيه واريـانس بخـششبنـدى فلـز روى (Zn)،

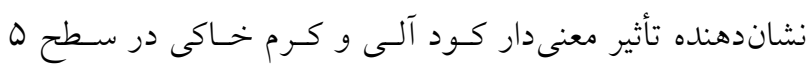
درصد روى بخش كربناته فلز روى است (جدول 9). يافتههـاى 


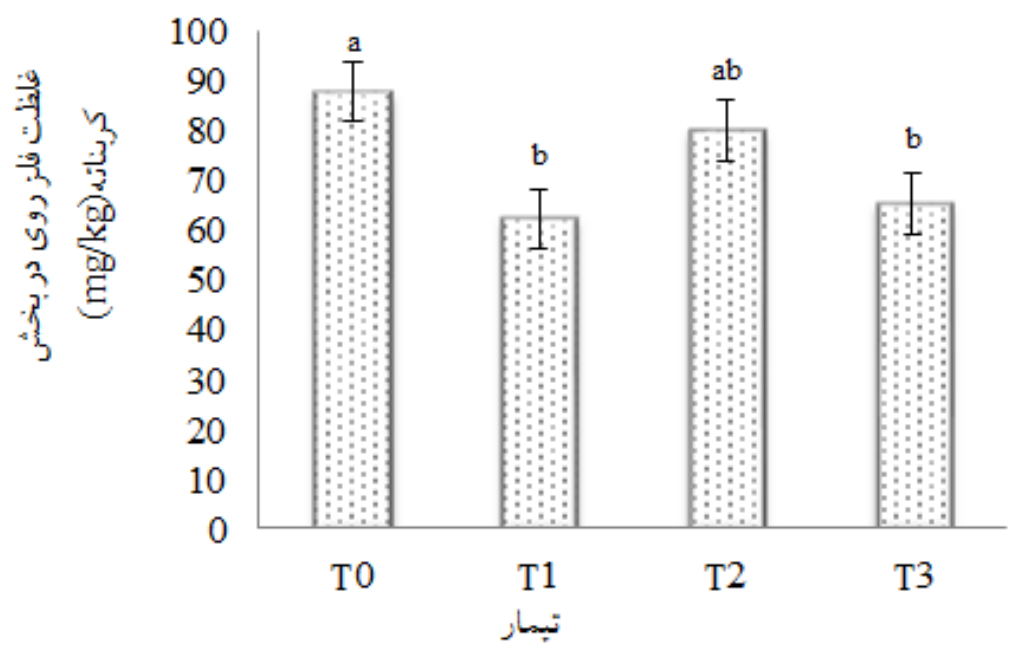

شكل 1. اثر كود آلى بر فلز روى در بخش كربناته خاك. T0، T1، T2، T3 بهرتيب نشاندهندة تيمار شاهد، تيمار كود كاوى، تيمار يورؤ

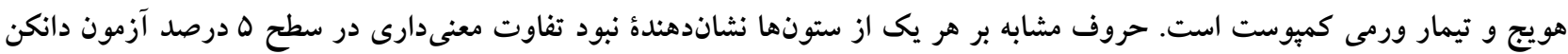
است. خطوط عمودى بر هر ستون نشاندهندة انحراف استاندارد دادهها است.

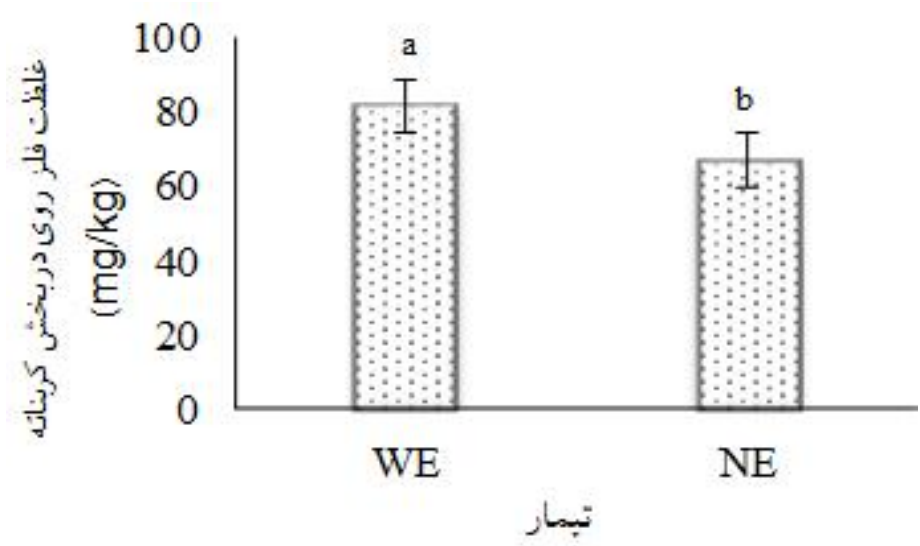

شكل r. اثر كرم خاكى بر فلز روى در بخش كربناته خاك. WE، بهترتيب نشاندهندة تيمار داراى كرم خاكى و بدون كرم خاكى است. حروف مشابه بر هر يك از ستونها نشاندهندة نبود تفاوت معنىدارى در سطح 1 درصد آزمون دانكن است. خطوط عمودى بر هر ستون نشاندهندة انحر اف استاندارد دادهها است.

فلز مس (جدول V) نشـان داد كـه تـأثير كـود آلى در سطح ه

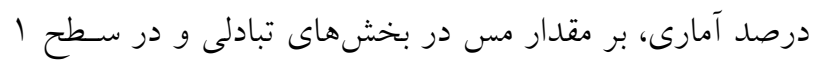

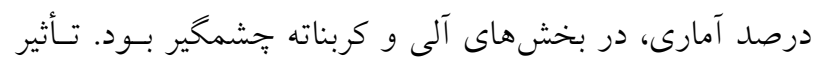

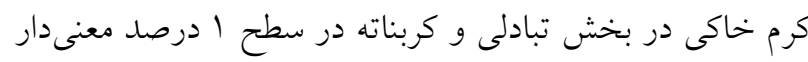

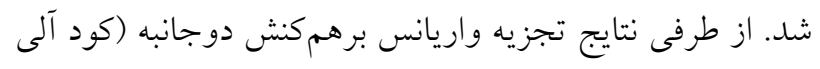

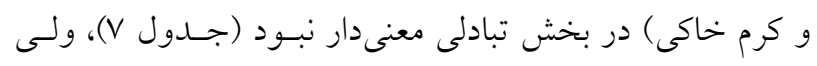

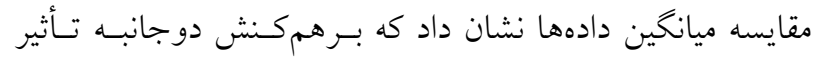

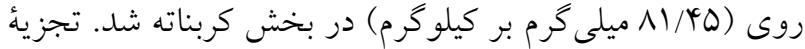

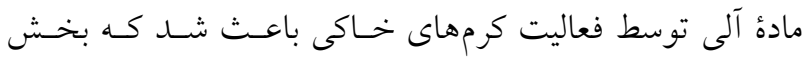

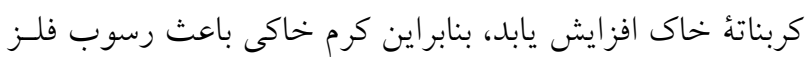

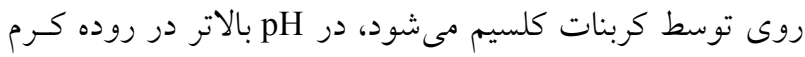

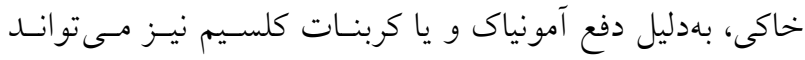
سبب رسوب فلز با كربناتها شود (هم).

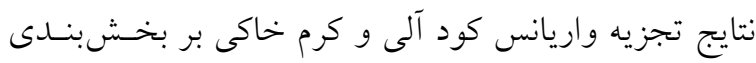


جدول V. نتايج تجزيه واريانس اثر كود آلى و كرم خاكى بر بخشبندى فلز مس

\begin{tabular}{|c|c|c|c|c|c|}
\hline \multicolumn{4}{|c|}{ ميانخين مربعات } & \multirow[b]{2}{*}{ درجه آزادى } & \multirow[b]{2}{*}{ منبع بر اكنش } \\
\hline بخش باقىمانده & بخش كربناته & بخش آلى & بخش تبادلى & & \\
\hline $1009 \mathrm{kns}$ & $\mu 19 \circ \Lambda^{* * * *}$ & $\left.r q\right|^{* * *}$ & $1 / 99^{*}$ & r & كود آلى \\
\hline$|Y q Y|^{\mathrm{ns}}$ & YIYYq*** & $r / \mathcal{\Psi} V^{n s}$ & $T / Y Y^{* * *}$ & 1 & كرم خاكى \\
\hline rMVTNns & 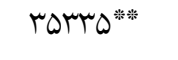 & $r V / \Delta^{n s}$ & $\circ / Y I^{\mathrm{ns}}$ & r & كود آلى × كرم خاكى \\
\hline$M \circ \Delta$ & $p / 4 q$ & $r \circ / N$ & $0 / 04$ & $1 \circ \wedge$ & خطا \\
\hline
\end{tabular}

ns

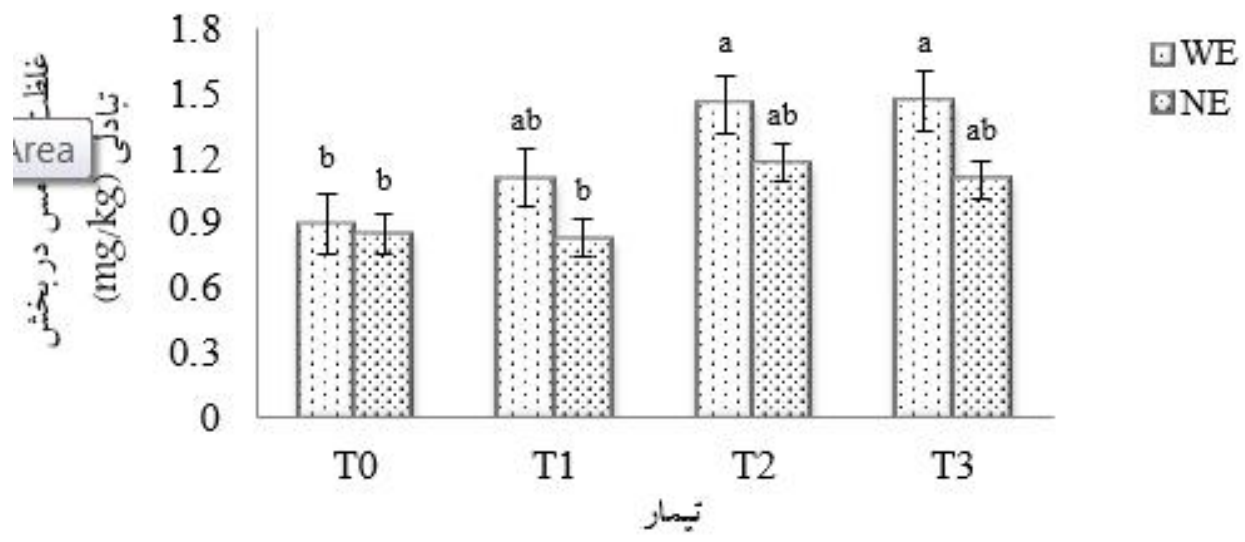

شكل r. اثر متقابل كود آلى و كرم خاكى بر فلز مس در بخش تبادلى خاك. T0، T1، T2، T3 بهترتيب نشاندهندة تيمار شاهد، تيمار كود كاوى، تيمار يورة هويج، تيمار ورمى كميوست و NE WE، بهتيب نشاندهندة تيمار داراى كرم خاكى و بدون كرم خاكى است. حروف

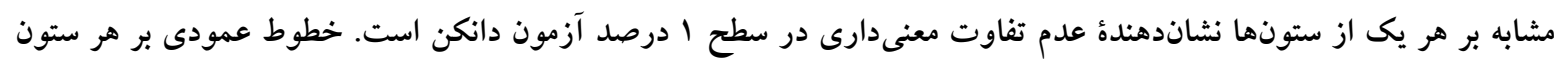
نشاندهندة انحر اف استاندارد دادهها است.

حلاليت و در دسترس بودن فلزات سنخين در خاك آلوده را تحت تأثير قرار مىدهد (q)). افزايش در كربن آلى مى دواند داند

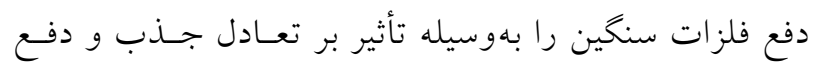

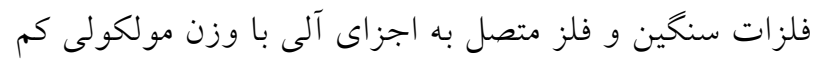

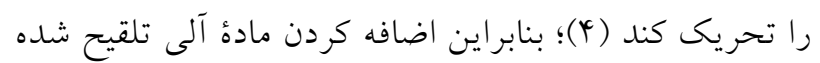

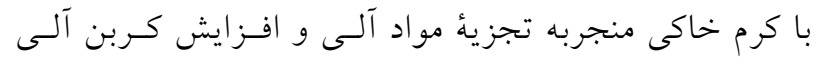

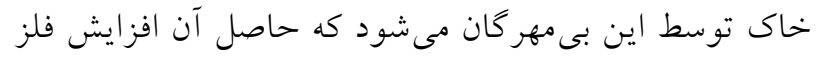
مس در بخش تبادلى است.

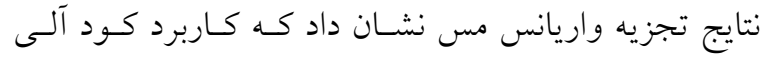
اثرات جشمخيرى روى بخش آلى اين فلز داشتند (جدولV). بـا سـا

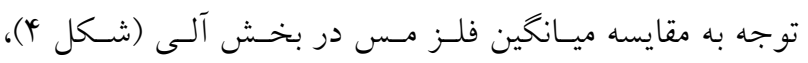

معنى دارى (در سطح ا درصد) بر مس تبـادلى داشـته اسـت

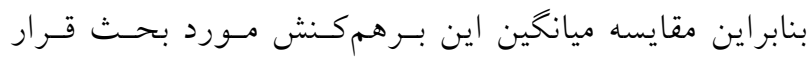

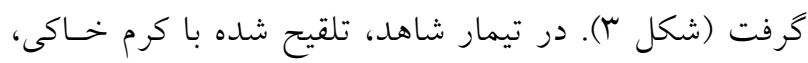

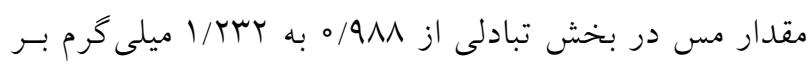
كيلو گرم افزايش يافت اما تفاوت معنى دارى بسين آنهـا ديسـده

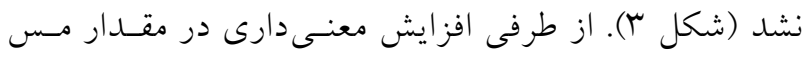

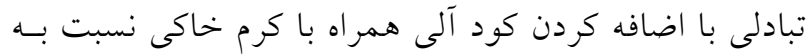
نمونه شاهد ديده شد كه اين افزايش در تيمار ورمى كميوست

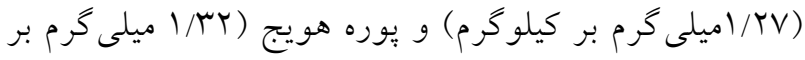

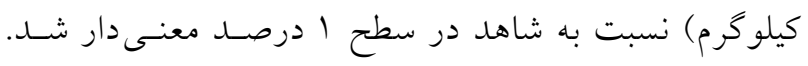

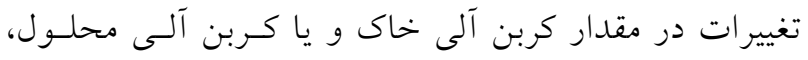




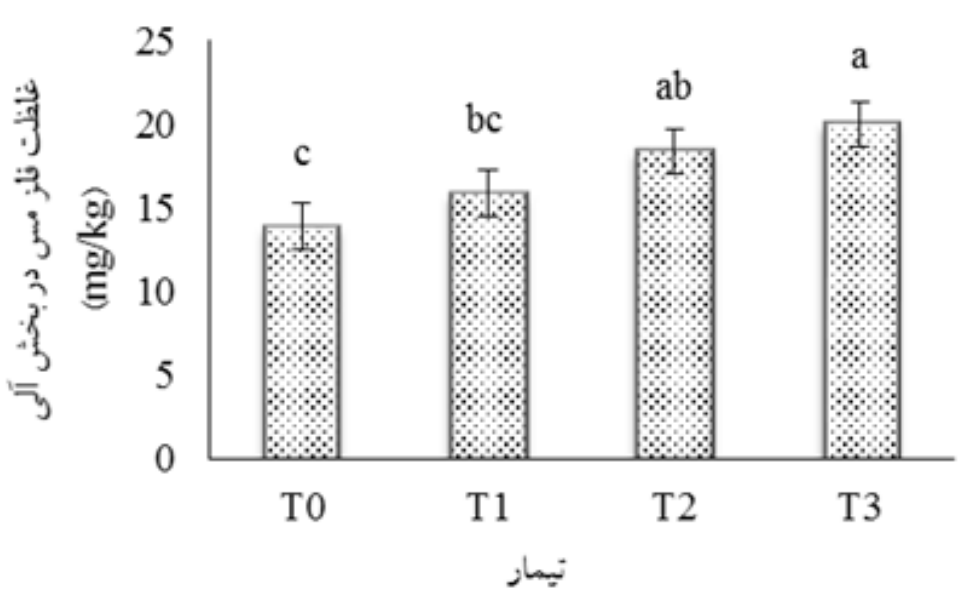

شكل f. اثر كود آلى بر فلز مس در بخش آلى خاك، T0، T2، T2، T3 به ترتب نشاندهنده تيمار شاهد، تيمار كود گاوى، تيمار بيوره هويج و تيمار ورمى كميوست است. حروف مشابه بر هر يك از ستونها نشاندهنده نبود تفاوت معنىدارى در سطح ا درصد آزمون دانكن است. خطوط عمودى بر هر ستون نشاندهندة انحراف استاندارد دادهها است.

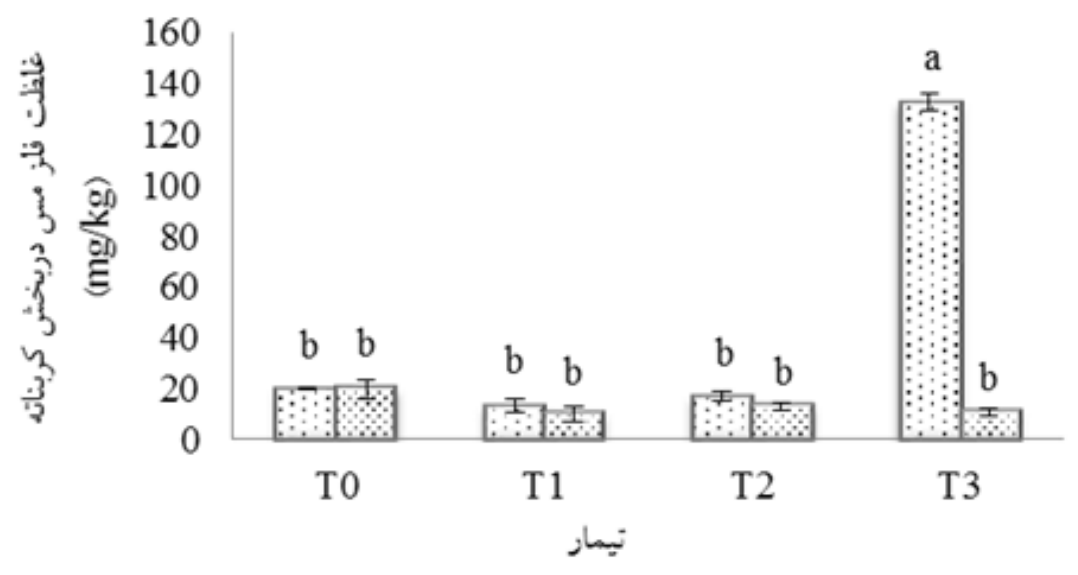

$\triangle \mathrm{WE}$

워NE

شكل ه. اثر متقابل كود آلى و كرم خاكى بر فلز مس در بخش كربناته، T0، T1، T2، T3 به ترتيب نشاندهندء تيمار شاهد، تيمار كود كاوى، تيمار بوره هويج، تيمار ورمى كميوست و WE WE بهترتيب نشاندهندهُ تيمار داراى كرم خاكى و بدون كرم خاكى است. حروف مشابه بر هر يك از ستونها نشاندهنده نبود تفاوت معنىدارى در سطح ا درصد آزمون دانكن است. خطوط عمودى بر هر ستون نشاندهندة انحر اف استاندارد دادهها است.

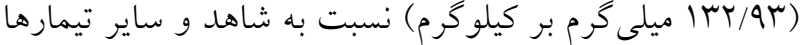
شد (شكل ه). اين يافته ها تا حدودى بـا نتـايج عبـاس يـور و كلجينين ( (1) كه كزارش كردند كه ورمى كميوست باعث افزايش بخش كربناته فلز مس و از طرفى باعث افزايش بخــش بيونـــ يافته به اكسيد منگنز مى شود، مطابقت داشت، والكـر (YV)، در مطالعاتى كه تأثير كود گاوى را بر توزيع مس بررسى كـرد بـه اين نتيجه رسيد كه كود كاوى باعـث كـاهش مس در بخـش
كاربرد ورمى كميوست و بـورةه هـويج بـهــور معنسىدارى (در سطح ( درصد) باعث افزايش مس در بخش آلى نسبت به تيمار شاهد شد. نتـايج ديخـر نشـان داد كـه ورمسى كميوسـت باعـث افزايش غلظت مس در بخش آلى مىشود كه با نتايج اين مطالعه مطابقت داشت (1) - (1). كاربرد تيمار ورمى كميوست تلقيح بـا كـرم خـاكى باعـث افزايش معنسى (در سـطح ار درصـد) غلظـت مسس كربناتـه 


$$
\begin{aligned}
& \text { نتيجه كيرى } \\
& \text { نتايج حاصل از اين مطالعه حاكى از آن است كه بر اتــ فعاليـت }
\end{aligned}
$$

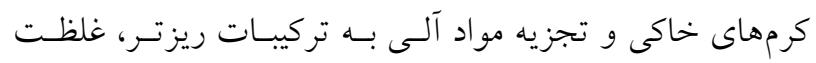

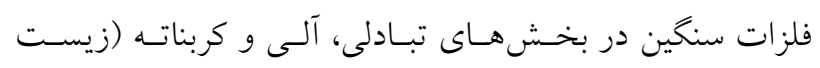

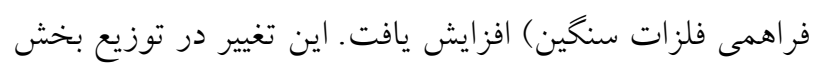

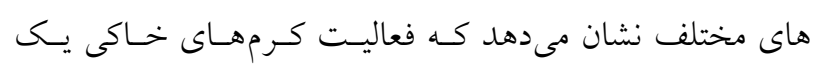

$$
\begin{aligned}
& \text { فاكتور مهم و تأثير گذار در توزيع فلزات در بخش هـآ دهاى مختلـف } \\
& \text { و زيست فراهمى آنها در ورمى كميوست است. }
\end{aligned}
$$$$
\text { كربناته و افزايش مس در بخش متصل به ماده آلى شده اسـت. }
$$$$
\text { از طرفى نقش كرمهاى خاكى را نبايد بىتأثير دانست، بسيارى }
$$$$
\text { از كونهاى كرم خاكى كربنات كلسـيم ( }
$$$$
\text { كرانولهايى از غــدد تخصصسى خـود، ترشـح مسى كنتـد، ايسن }
$$$$
\text { كرانولها بيشتر بهشـكل كلسـيت بـا مقــار كمسى از آمسورف }
$$$$
\text { كربنـات كلسـيم و آراخونيـت اسـت (9). از طرفـى فعاليـت }
$$$$
\text { كرمهاى خاكى باعث تجزئه مادهُ آلى مسى شـود كـه مسىتوانـد }
$$$$
\text { بخش كربناتهٔ مواد آلى خـاك را افـزايش دهـــ بنـابراين كـرم }
$$$$
\text { خاكى باعث رسوب فلز توسط كربنات كلسيم مىشود. }
$$

\section{منابع مورد استفاده}

1. Abbaspour, A. and A. Golchin. 2011. Immobilization of heavy metals in a contaminated soil in Iran using diammonium phosphate, vermicompost and zeolite. Environmental Earth Sciences 63: 935-943.

2. Adriano D. 1986. Heavy Metals in the Environment. Springer-Verlag. New York.

3. Arnold, R. and M. Hodson. 2007. Effect of time and mode of depuration on tissue copper concentrations of the earthworms Eisenia andrei, Lumbricus rubellus and Lumbricus terrestris. Environmental Pollution 148: 21-30.

4. Antoniadis, V. and B. Alloway. 2002. The role of dissolved organic carbon in the mobility of $\mathrm{Cd}, \mathrm{Ni}$ and $\mathrm{Zn}$ in sewage sludge-amended soils. Environmental Pollution 117: 515-521.

5. Barceloux, D. G. 1999. Zinc. Journal of Toxicology: Clinical Toxicology 37(2): 279-292.

6. Bauycos G. J. 1962. Hydrometer methods improved for making particle size of soils. Agronomy Journal 56: 464465.

7. Berlin, M. 1985. Handbook of the Toxicology of Metals. Elsevier Science Publishers, 2nd ed. London.

8. Bhagwant, S. and M. Bhikagee. 2000. Induction of hypochromic macrocytic anemia in Oreohromis hybrid the dependency on exposure time. Ecotoxicology and Environmental Safety 9(2): 179-188.

9. Brinza, L., P. D. Quinn, P. F. Schofield, J. F. W. Mosselmans and M. E. Hodson. 2013. Incorporation of strontium in earthworm-secreted calcium carbonate granules produced in strontium-amended and strontium-bearing soil. Geochimica et Cosmochimica Acta 113: 21-37.

10. Dai J., T. Becquer, J. H. Rouiller, G. Reversat, F. Bernhard-Reversat, J. Nahmani and P. Lavelle. 2004. Heavy metal accumulation by two earthworm species and its relationship to total and DTPA-extractable metals in soils. Soil Biology and Biochemistry 36: 91-98.

11. Eijsackers, H. 2010. Earthworms as colonisers: Primary colonisation of contaminated land, and sediment and soil waste deposits. Science of the Total Environment 408: 1759-1769.

12. Faiz, Y., M. Tufail, M. T. Javed and M. Chaudhry. 2009. Road dust pollution of $\mathrm{Cd}, \mathrm{Cu}, \mathrm{Ni}, \mathrm{Pb}$ and $\mathrm{Zn}$ along Islamabad Expressway. Pakistan. Microchemical Journal 92: 186-192.

13. Feng Peng, F., Y. Hui Song, P. Yuan, X. Cui and G. Qiu. 2009. The remediation of heavy metals contaminated sediment. Hazardous Materials 161: 633-640.

14. Hopkin, S. 1995. Deficiency and Excess of Essential and Non-essential Metals in Terrestrial Insects. Insects in a Changing Environment. Academic Press, London.

15. Hashemi, H, A. Khodabakhshi, B. Alinia and F. Abbasi. 2018. Bioremediation of lead and zinc contaminated soils by compost worm. Journal of Health Sciences \& Surveillance System 6(2): 58-63.

16. Heseu, Z. Y. 2006. Extractability and bioavailability of zinc over time in three tropical soils incubated with biosolids. Chemosphere 63(5): 762-771.

17. Hobbelen, P., J. Koolhaas and C. Van Gestel. 2006. Bioaccumulation of heavy metals in the earthworms Lumbricus rubellus and Aporrectodea caliginosa in relation to total and available metal concentrations in field soils. Environmental Pollution 144: 639-646.

18. Ismaili Sari, A. 2006. Pollutants of Health and Standards in the Environment. Naghshe Mehr Publications, Tehran.

19. Kizılkaya R. 2005. The role of different organic wastes on zinc bioaccumulation by earthworm Lumbricus terrestris L.(Oligochaeta) in successive Zn added soil. Ecological Engineering 25(4): 322-331. 
20. Lanno, R., J. Wells, J. Conder, K. Bradham and N. Basta. 2004. The bioavailability of chemicals in soil for earthworms. Ecotoxicology and Environmental Safety 57: 39-47.

21. Li, Z., Z. Ma, T. J. van der Kuijp, Z. Yuan and L. Huang. 2014. A review of soil heavy metal pollution from mines in China: pollution and health risk assessment. Science of the Total Environment 468: 843-853.

22. Li, L. Z., D. M. Zhou, P. Wang, H. E. Allen and S. Sauvé. 2009. Predicting Cd partitioning in spiked soils and bioaccumulation in the earthworm Eisenia fetida. Applied Soil Ecology 42(2): 118-123.

23. Matscheko, N., S. Lundstedt, L. Svensson, J. Harju and M. Tysklind. 2002. Accumulation and elimination of 16 polycyclic aromatic compounds in the earthworm (Eisenia fetida). Environmental Toxicology and Chemistry 21(8): 1724-1729.

24. Nannoni, F., G. Protano and F. Riccobono. 2011. Uptake and bioaccumulation of heavy elements by two earthworm species from a smelter contaminated area in northern Kosovo. Soil Biology and Biochemistry 43(12): 2359-2367.

25. Nahmani, J., M. E. Hodson and S. Black. 2007. A review of studies performed to assess metal uptake by earthworms. Environmental Pollution 145: 402-424.

26. Nahmani, J., M. E. Hodson, S. Devin and M. G. Vijver. 2009. Uptake kinetics of metals by the earthworm Eisenia fetida exposed to field-contaminated soils. Environmental Pollution 157(10): 2622-2628.

27. Peijnenburg, W. and T. Jager. 2003. Monitoring approaches to assess bioaccessibility and bioavailability of metals: matrix issues. Ecotoxicology and Environmental Safety 56: 63-77.

28. Rowell, D. L. 1994. Soil Science Methods and Application, part7. Mesurement of the Composition of Soil Solution.

29. Reinecke, A. J. 1992. A review of ecotoxicological test methods using earthworms. PP. 7-19. In: Greig-Smith P. W., H. Becker, P. J. Edwards and F. Heimbach (Eds.), Ecotoxicology of Earthworms. Intercept, Hants.

30. Roades J. D. 1996. Salinity: Electrical Conductivity and Total Dissolved Solids. Method of Soil Analysis, Parss: Chemical Methods. Madison. Wisconsin, USA.

31. Sizmur, T. and M. E. Hodson. 2009. Do earthworms impact metal mobility and availability in soil? -A review. Environmental Pollution 157(7): 1981-1989.

32. Slizovskiy, I. B. and J. W. Kelsey. 2010. Soil sterilization affects aging-related sequestration and bioavailability of p, p'-DDE and anthracene to earthworms. Environmental Pollution 158(10): 3285-3289.

33. Spurgeon, D. and S. Hopkin. 1999. Comparisons of metal accumulation and excretion kinetics in earthworms (Eisenia fetida) exposed to contaminated field and laboratory soils. Applied Soil Ecology 11: 227-243.

34. Sposito, G., L. J. Lund and A. C. Chang. 1982. Trace metal chemistry in arid zone field soils amended with sewage sludge: i. fractionation of $\mathrm{Ni}, \mathrm{Cu}, \mathrm{Zn}, \mathrm{Cd}$ and $\mathrm{Pb}$ in solid phases. Journal of Soil Science Society of America 46: 260264.

35. Sun, H, J. Li, C. Wang, L. Wang and Y. Wang. 2011. Enhanced microbial removal of pyrene in soils in the presence of earthworms. Soil and Sediment Contamination: An International Journal 20(6): 617-630.

36. Udovic, M. and D. Lestan. 2010. Fractionation and bioavailability of $\mathrm{Cu}$ in soil remediated by EDTA leaching and processed by earthworms (Lumbricus terrestris L. Environmental Science and Pollution Research 17: 561-570.

37. Walker, D. J., R. Clemente, R. and M. P. Bernal. 2004. Contrasting effects of manure and compost on soil pH, heavy metal availability and growth of Chenopodium album L. in a soil contaminated by pyritic mine waste. Chemosphere 57(3): 215-224.

38. Walkey, A. and I. A. Black. 1934. An examination of the degtjareff method for determining soil organic matter and a proposed modification of the chromic acid titration method. Soil Science 37: 29-38.

39. Wang, Z. -Z., Y. -M. Zhang, Y. -C. Guo, W. -S. Xia, Z. -W. Li and J. -F. Deng. 2007. Monitoring of soil heavy metal pollution by earthworm. Journal of Environmental Sciences(China) 10: 437-444. 


\title{
The Role of Earthworms (Eisenia fetida) on the Bioavailability of Contaminated Soil with Heavy Metals
}

\author{
G. Rahimi* and F. Noruzi Goldareh ${ }^{1}$
}

(Received: January 14-2020 ; Accepted: July 26-2020)

\begin{abstract}
Earthworms are soil organisms commonly used in environmental studies and biological toxicology. Therefore, the present study aimed to investigate the role of Eisenia Fetida earthworms on the bioavailability of zinc and copper in the contaminated soils. This study was carried out on a contaminated soil sampled from the Ahangaran mine 26 kilometers far from the city of Malair and its surrounding areas. In this experiment, 12 earthworms with the average weight of 0.3 $-0.6 \mathrm{~g}$ were selected for each soil sample. The worms were exposed to a metal contaminated soil for 42 days. After the test time, Zinc $(\mathrm{Zn})$ and Cupper $(\mathrm{Cu})$ concentrations were measured in different fractions of the soil. The results showed that cow manure, carrot pulp and vermicompost significantly reduced (at the level of 5\%) $62.2,80$ and $65.2 \mathrm{mg} / \mathrm{kg}$ of the metal zinc concentration in carbonate, respectively, as compared to the treatment control. Earthworms significantly increased zinc $(81.45 \mathrm{mg} \mathrm{kg})$ in the carbonate fraction. On the other hand, there was a significant increase in the amount of exchangeable copper with the addition of organic fertilizer to worm, as compared to the control sample. This increase was significant (at the level of 1\%) in the treatment of Vermicompost $(1.27 \mathrm{mg} / \mathrm{kg})$ and carrot pulp $(1.32 \mathrm{mg}$ $/ \mathrm{kg}$ ), as compared to control.
\end{abstract}

Keywords: Fractionation of metals, Earthworms, Copper and Zinc metals

1 Soil Science Department., Bou-Ali Sina University, Hamedan, Iran.

*: Corresponding author, Email: g.rahimi@basu.ac.ir 